\title{
French Nuclear Testing in the South \\ Pacific, or When France Makes Light \\ of Its Duty to Remember
}

Gabriel Tetiarahi

$\mathrm{O}_{\mathrm{n}}$

n I3 June I995, when President Jacques Chirac announced a final round of a dozen nuclear tests [in French Polynesia], his irrevocable decision caused concern and dismay. Without bothering at all to first consult the Polynesian people, he committed an act of gratuitous violence against these people and their representatives, political parties, churches, labor unions, and nongovernmental organizations. It felt like a planned assassination of this child-all the future generations carried by the mothers in their wombs, their pu fenua-by the new occupant of the Elysée [the French "White House"].

Of course, Chirac could always count on his constant "brother," the president of the territorial government, Gaston Flosse. His campaignsspread by the media of the Hersant group and by Radio Overseas France in favor of the tests' harmlessness and of the I, ,oo new jobs that the program would generate-could not change the public opinion of the great majority, under the morally aggressive blow.

Demonstrations, support from throughout the Pacific region, and the massive presence of international media accompanied the testimonies of those who had directly suffered from the explosions, whether atmospheric or underground. The riots in Papeete were only the logical outcome of an act of violence committed by two dignitaries, Jacques Chirac and Gaston Flosse. In looking elsewhere for the culprits, the police and courts failed in their mission. The nuclear criminals were successive presidents of the French Republic, from De Gaulle to Chirac, and not the Polynesians, who were more victims than culprits.

They had also tarnished the image of France. Chirac decided then to end the tests once and for all in January I996. The opponents of nuclear

The Contemporary Pacific, Volume I7, Number 2, 378-38I

(C) 2005 by University of Hawai'i Press 
testing could hardly cry victory, however. Would France wash its hands of the experiments, without taking into consideration the impact of atomic testing on the environment and especially the health of veterans, both civilian Polynesian workers and French soldiers?

From its side, to clear its conscience, France commissioned a radiological study by the International Atomic Energy Agency. Its conclusions were made public at the French Pacific University in Papeete, but far from calming concerns among Polynesians, the results raised fears. ${ }^{1}$ The conclusions contradicted in a shocking manner the information from previously classified military sources, according to which Moruroa and Fangataufa would not be contaminated. Thirty-five years of lies, and in addition, no investigation of the aerial tests had been conducted.

Seeking another truth, the Evangelical Church and the network of nongovernmental organizations, Hiti Tau, are working together with the support of European organizations to give voice to the former workers who agreed to break the silence that surrounded the nuclear crime sites. The conclusions of a study published in 1997 are revealing. Children as young as ten to fourteen years old were enlisted to work on Moruroa. We thought slavery had been abolished in I 848 . Access to medical files is still cloaked in secrecy. Under such conditions it was easy for military doctors to claim there was no link between the rise in cancers among the workers and the radioactivity of the experiments.

Conferences held in 1999 in the very heart of the National Assembly in Paris, in which a few French parliamentarians participated, hardly pushed the highest authorities of the French State to admit finally that France had not conducted clean tests, let alone admit their impact on the health of Polynesians, for whom ceaseless reports of thyroid cancers, the highest rate in the world among women, became daily worries.

The reelection of Chirac in 2002 did nothing to change his will to remain mute on the repercussions. He could, traditionally, ally himself with his constant brother Flosse, who emerged victorious in the ballot boxes in $200 \mathrm{I}$ and continued to receive generous economic support from the French State. ${ }^{2}$ A reconversion fund fed annually by I 8 billion CFP in French subsidies was put in place as compensation. A judicial immunity (naturally supported by the Free Masons) cloaked all the exaggerations and diversions of the local government. Directives were given to the French high commissioner in Polynesia to be increasingly lenient about the legality and the legitimacy of the territorial government. Look at the political contract that bound for life the two powerful men of the Union for 
the Presidential Majority (UMP) of the heir of General De Gaulle in Paris and the Tahoeraa Huiraatira [party] in Papeete, from whom the Elysée demanded, in exchange, a blind silence about the Polynesian requirements of truth and transparency about the atomic experiments-and a total adherence to Chirac's will to favor a more massive immigration of French citizens into the Islands, without any administrative obstacles that might hinder their establishment from the viewpoint of acquiring land or jobs. In addition to this price that the Polynesians pay today so that France can keep a few pieces of "confetti" from its former colonial empire in the South Pacific, the local government began, under pressure from the French state, a long and meticulous task of erasing the collective memory of the Polynesians.

For a long time, from I963-I996, the Maohi sacrificed human lives at Moruroa and at Fangataufa while permitting France to undertake "the construction of its nuclear force" and to conserve in the Security Council of the United Nations its rank of a mid-level world power. And Chirac recalled that during his last visit in July 2003, "France owes a lot to Polynesia, which enabled it to keep its national independence." Since 2002, and a long time before that, the Polynesians have never succeeded in obtaining from their government's president another look at their health agonies. He and his entourage consider the attachment to France as only a rampart to avert crises like those in Fiji, Solomon Islands, and Bougainville. There is manifestly worse that sleeps in the bowels of Moruroa and Fangataufa. When the time of awakening to the escaping radioactivity comes, it will perhaps be too late. There is no worse inheritance to leave to future generations than that of radioactive contamination. And yet that is what the two brothers Jacques and Gaston decided to give as a destiny to the indigenous people of the Pacific, to the Maohi and the rest of the countries of the liquid continent, the Pacific. Such a stubbornness not to feel concern for the dangers and risks that peoples incur is a crime against humanity.

In closing, the article by Jean-Marc Regnault clearly raises questions for the reader about the role of the French Pacific University in the region but also about the indoctrination of young students' opinions into a uniform system of thought that its teachers choose to serve, without scruples and without dissent. There is no greater evidence than to say that the university chose the camp of those who think that France owes nothing to the Maohi Nation, from the perspective of the health of the former workers of Moruroa and Fangataufa.

If the occupants of the Elysée and of Matignon refuse to recognize the 
responsibility of the French State for the consequences of the testing program conducted in the Tuamotu Islands for thirty-five years, it shows clearly that French arrogance, so suited to the Rassemblement pour la République [Chirac's Rally for the Republic party] and now to the Union for the Presidential Majority, has chosen not to distance itself from the shores of the Pacific. And yet, it no longer has its place here.

\section{Section Editor's Notes}

I The International Atomic Energy Agency report of 1998 concluded that no remedial action was needed to clean up Moruroa or Fangataufa atolls and that no ongoing environmental monitoring was necessary. However, it did admit that early aboveground testing had deposited five kilograms of plutonium in the bottom of Moruroa lagoon and three kilograms in Fangataufa lagoon, that another five hundred kilograms of plutonium waste lie in sealed cavities under the atolls, and that the radioactive tritium in Moruroa lagoon is ten times higher than in the surrounding ocean, because of leakage through cracks in the atoll rock. In short, the report said that contamination had occurred, but that it would not affect the sea around the atolls for centuries. Yet no geological study has been conducted of the atoll, and no statistics were collected to show how the radiation at the times of actual testing affected neighboring populations; moreover, a significant part of the data used in the report was supplied by the French government and was validated with independent samplings, under French supervision, only "when practicable." Sources: "The Legacies of Moruroa and Fangataufu," published by WISE News Communique on 2 I August I998 < http://www.antenna.nl/wise/496/4906 .html> and "What Lies Beneath: Assessing the Impact of France's Nuclear Tests," by Sandra Radu, Harvard International Review 2003-2004 < http://hir.harvard .edu/articles/index.html?id $=1007>$.

2 Since this essay was written, Flosse was defeated in the 2004 election and replaced as president of French Polynesia by Oscar Temaru, who is pursuing the contamination issue with France. 